\title{
Implementasi dan Analisis Kompresi Hybrid pada Citra Medis Digital Hasil Rontgen Kanker Payudara
}

\author{
Randy Hamzah Hardianto ${ }^{1}$, Ledya Novamizanti ${ }^{2}$, Anggunmeka Luhur Prasasti ${ }^{3}$ \\ ${ }^{1,2}$ Prodi S1 Teknik Telekomunikasi, Fakultas Teknik Elektro, Telkom University \\ ${ }^{3}$ Prodi S1 Sistem Komputer, Fakultas Teknik Elektro, Telkom University \\ 1,2,3 Jalan Telekomunikasi No.1, Terusan Buah Batu, Bandung 40257 \\ ${ }^{1}$ randy.hamzah.h@gmail.com, ${ }^{2}$ ledyaldn@telkomuniversity.ac.id, \\ 3anggunmeka@telkomuniversity.ac.id
}

\begin{abstract}
Digital image compression is an attempt to transform the data or symbols of composing digital images into data or other symbols without causing significant changes in the digital image to the human views. The goal is to reduce the redundancy of the data contained in the image so it can be stored or transmitted efficiently. Breast cancer is one of the greatest cancer cases in Indonesia which requires so many digital data $x$-rays. This research is intended to compress digital $X$-ray images of breast cancer with more efficient size without altering or reducing its information and it still can be assessed by human view. Using hybrid compression method, they are $2 D$ DCT (Two Dimensional Discret Cosine Transform) and Huffman Method, Medical expert gave 3 of 4 rate when it reach $34.36 \%$ compression ratio with 40dB PSNR. This test result used 0 till 3 depth of zero in $2 D$ DCT quantization process.

Keywords-- Compression, Medical Image, Two Dimensional Discrete Cosine Transform (2D DCT), Huffman Transform.
\end{abstract}

Intisari-- Kompresi citra digital merupakan upaya untuk melakukan transformasi terhadap data atau simbol penyusunan citra digital menjadi data atau simbol lain tanpa menimbulkan perubahan yang signifikan atas citra digital tersebut bagi mata manusia yang mengamatinya. Tujuannya adalah untuk mengurangi redudansi dari data-data yang terdapat dalam citra sehingga dapat disimpan atau ditransmisikan secaran efisien. Kanker Payudara merupakan kasus kanker terbanyak di Indonesia, dimana penatalaksanaannya membutuhkan banyak sekali data digital hasil rontgen. Penelitian ini dimaksudkan untuk mengompres data digital hasil rontgen kanker payudara dengan ukuran yang lebih efisien tanpa mengubah atau mengurangi informasi serta masih dapat dinilai oleh pandangan manusia (ekspertis). Penelitian ini menggunakan teknik hybrid, yaitu Metode 2D DCT (Two Dimensional Discret Cosine Transform) dan Huffman. Tenaga Medis memberikan nilai 3 dari 4 ketika hasil kompresi mencapai rasio kompresi 34,36\% dengan PSNR terbaik sebesar 40dB. Hasil pengujian ini menggunakan kedalaman nilai nol sebesar 0 hingga 3 pada proses kuantsasi 2D DCT.

Kata Kunci-- Kompresi, Citra Medis, Two Dimentional Discrete Cosine Transform (2D DCT), Huffman Transform.

\section{PENDAHULUAN}

Kanker payudara merupakan salah satu jenis kanker terbanyak yang diderita pasien di Indonesia. Hingga tahun 2015, berdasarkan data Sistem Informasi RS (SIRS), jumlah pasien rawat jalan maupun rawat inap pada kanker payudara merupakan kasus terbanyak, yaitu 12.014 orang $(28,7 \%)$ dan kanker serviks 5.349 orang $(12,8 \%)^{[4]}$. Untuk mengetahui jenis penyakit ini, perlu dilakukan foto rontgen payudara. Kualitas citra digital hasil rontgen tersebut harus baik sehingga memudahkan tim medis dalam mendeteksi kemungkinan adanya penyakit pada payudara pasien. Citra medis (foto rontgen) digital tersebut memiliki ukuran data yang sangat besar sehingga membutuhkan memori penyimpanan yang juga sangat besar untuk puluhan ribu pasien penderita kanker payudara. Maka dari itu, perlu dilakukan kompresi dengan batasan yang efisien tanpa menghilangkan informasi penting yang ada didalamnya. Selain untuk menghemat penyimpanan, kompresi citra medis digital ini bertujuan untuk mempercepat proses transfer data. Pada penelitian sebelumnya, disimpulkan bahwa DCT membutuhkan sedikit daya pemrosesan, namun menghasilkan rasio kompresi yang kurang ${ }^{[5]}$. Teknik 2D DCT menghasilkan penurunan kualitas gambar yang kecil, akibatnya kebutuhan penyimpanan berkurang dan mempercepat proses transmisi ${ }^{[2]}$. Teknik Kompresi 2D DCT juga mengurangi block artifak dan dapat meningkatkan kualitas citra ${ }^{[2]}$. Berdasarkan penelitian sebelumnya diketahui bahwa kompresi DCT saja tidak cukup efektif karena masih memiliki rasio kompresi yang rendah meskipun kualitas gambar yang dihasilkan baik. Moh'd Ali Moustafa Alsayyh melakukan eksperimen hibrida teknologi kompresi DCT dan DWT yang sangat baik untuk mengatasi masalah rasio kompresi ${ }^{[6]}$. Setelah menerapkan teknik lossy lebih baik menggunakan teknik lossless juga untuk meningkatkan kompresi pada PSNR. Pada penelitian hibrida DCT-DWT $^{[7]}$ menyimpulkan DCT memiliki transformasi cepat dan memiliki citra tetap yang memberikan kompromi yang baik antara kemampuan pengepakan informasi dan komputasi kompleksitas. Skema hibrida berkinerja lebih baik di lingkungan yang banyak noise dan mengurangi kesalahan efek berkontur serta mampu mengurangi artefak secara signifikan. Artinya teknik hibrida menghasilkan PSNR yang lebih tinggi sehingga performansi gambar hasil kompresi jadi lebih baik. 
Kompresi DCT merupakan kompresi yang bersifat lossy. Teknologi hibrida sangat efektif jika dikombinasikan dengan teknik kompresi yang bersifat lossless. Selain DWT, kompresi Huffman merupakan kompresi yang bersifat lossless yang cukup efektif dikombinasikan dengan DCT. Algoritma Huffman menggunakan prinsip pengkodean yang mirip dengan kode Morse, yaitu tiap karakter (simbol) dikodekan hanya dengan rangkaian beberapa bit, dimana karakter yang sering muncul dikodekan dengan rangkaian bit yang pendek dan karakter yang jarang muncul dikodekan dengan rangkaian bit yang lebih panjang ${ }^{[8][9]}$.

Pada penelitian ini, setelah dilakukan uji coba kompresi menggunakan 2D DCT ternyata rasio kompresi masih cukup kecil dan PSNR kecil sehingga teknik kompresi ini perlu dikombinasikan dengan metode kompresi lainnya (hybrid). Berdasarkan beberapa referensi yang digunakan, maka pada penelitian ini dilakukan kompresi citra medis menggunakan metode hybrid lossy dan lossless, yaitu 2D DCT (Two Dimensional Discrete Cosine Transform) dan Huffman untuk mendapatkan hasil kompresi yang optimal dan efisien.

\section{LANDASAN TEORI}

Discrete Cosine Transform (DCT) pada dasarnya mirip dengan Discrete Forier Trasnform (DFT), DCT dapat mengubah sinyal atau gambar dari domain spasial ke dalam domain frekuensi, mengambil informasi dari sinyal dan dikonsentrasikan hanya pada beberapa koefisien DCT. Karena sifatnya tersebut, DCT banyak digunakan dalam pengaplikasian sains dan teknologi, umumya pada lossy compression, misalnya pada kompresi audio MP3 dan gambar JPEG ${ }^{[10]}$.

Discrete Cosine Transform memiliki dua sifat utama dalam kompresi citra, yaitu mengkonsentrasi energi citra dalam jumlah kecil koefisien (Energy Compaction) dan meminimalkan ketergantungan antara koefisien satu dan yang lainnya (decorellation). ${ }^{[2]}$

DCT mengolah gambar dengan memisahkan gambar dalam sub-sub bagian dengan frekuensi yang berbeda-beda. Frekuensi yang memiliki nilai informasi sedikit akan dihilangkan kemudian frekuensi yang memiliki nilai informasi paling penting akan dipertahankan. Komponenkomponen frekuensi yang tersisa akan digunakan untuk mendekomposisi gambar menjadi seperti semula. Disinilah proses kompresi lossy DCT terjadi. ${ }^{[1]}$

Teknik DCT terdiri dari discrete cosine transform 1dimension, dan discrete cosine transform 2-dimension. Pada DCT satu dimensi, berguna untuk mengolah sinyal-sinyal yang berdimensi satu, seperti bentuk gelombang suara. Sedangkan untuk citra yang merupakan sinyal dua dimensi dibutuhkan versi dua dimensi dari DCT, yaitu discrete cosine transform 2-dimension.

\section{A. Discrete Cosine Transform (DCT) 1D dan 2D}

Two Dimentional Discrete Cosine Transform digunakan untuk mengkompresi gambar. Transformasi diskrit pada DCT-2D dinyatakan dalam bentuk persamaan. Adapun persamaan umum dari DCT-1D ( $N$ data items) dapat didefinisikan sebagai berikut:

$$
F(u)=\left(\frac{2}{N}\right)^{\frac{1}{2}} \sum_{i=0}^{N-1} \wedge(i) \cdot \cos \left[\frac{\pi u}{2 \cdot N}(2 i+1)\right] f(i)
$$

untuk $u=0,1,2, \ldots \ldots, N-1$

DCT-2D merupakan perbandingan dari DCT-1D. Adapun persamaan umum dari DCT-2D ( $N$ by $M$ Image) dapat didefinisikan sebagai berikut:

$$
\begin{aligned}
\mathrm{F}(\mathrm{u}, \mathrm{v})=\left(\frac{2}{\mathrm{~N}}\right)^{\frac{1}{2}} & \left(\frac{2}{M}\right)^{\frac{1}{2}} \sum_{\mathrm{i}=0}^{\mathrm{N}-1} \sum_{j=0}^{M-1} \wedge(i) \\
& \wedge(j) \cdot \cos \left[\frac{\pi \mathrm{u}}{2 \cdot \mathrm{N}}(2 \mathrm{i}+1)\right] \cos \left[\frac{\pi \mathrm{v}}{2 \cdot \mathrm{M}}(2 \mathrm{j}\right. \\
& +1)] \cdot \mathrm{f}(\mathrm{i}, \mathrm{j})
\end{aligned}
$$

untuk $u=0,1,2, \ldots \ldots, N-1$ dan

$v=0,1,2, \ldots \ldots, M-1$, sedangkan

$\wedge(k)= \begin{cases}\frac{1}{2}, & k=0 \\ 1, & k \neq 0\end{cases}$

Invers Discrete Cosine Transform Dua (IDCT-2D) dapat diperoleh dari rumusan sebagai berikut ini:

$$
\begin{aligned}
& f(\mathrm{x}, \mathrm{y}) \\
& =\left(\frac{2}{\sqrt{\mathrm{MN}}}\right) \sum_{\mathrm{u}=0}^{\mathrm{N}-1} \sum_{v=0}^{M-1} \propto(u) \\
& \propto(v) C(u, v) \cos \left(\frac{\pi(2 x+1) u}{2 \mathrm{~N}}\right) \cos \left(\frac{\pi(2 x+1) v}{2 \mathrm{M}}\right)
\end{aligned}
$$$$
\text { dengan nilai } x=0,1,2, \ldots, \mathrm{N}-1 \text { dan nilai } y=0,1,2 \text {, }
$$

... M-1.

Fungsi basis Discrete Cosine Transform 2 dimensi adalah sebagai berikut :

$$
\begin{aligned}
& C(\mathrm{x}, \mathrm{y}, \mathrm{u}, \mathrm{v})=\frac{2}{\sqrt{\mathrm{MN}}} \propto(u) \\
& \propto(v) C(u, v) \cos \left(\frac{\pi(2 x+1) u}{2 \mathrm{~N}}\right) \cos \left(\frac{\pi(2 x+1) v}{2 \mathrm{M}}\right)
\end{aligned}
$$

dengan nilai $\underline{u \text { dan }} x=0,1,2, \ldots, \mathrm{N}-1$ dan nilai $v$ dan $y=0,1,2, \ldots$ M-1. ${ }^{[2]}$

\section{B. Zigzag Coding}

Proses dari Zigzag coding dapat dilihat pada gambar berikut:

\begin{tabular}{|l|l|l|l|l|l|l|l|l|l|l|}
\hline \\
\hline 2 \\
4
\end{tabular}




\section{Gambar 1. Proses Zigzag Coding}

Zigzag coding dilakukan untuk mengubah data piksel menjadi data linier. Huffman coding membutuhkan data masukkan berupa data linier maka dari itu proses Zigzag coding diperlukan agar dapat dilakukan proses Huffman coding.

Inverse Zigzag Coding adalah proses kebalikan dari proses zigzag coding. Inverse Zigzag Coding mengembalikan deret angka ke dalam bentuk matriks berukuran $256 \times 256$.

\section{Algoritma Huffman}

Algoritma Huffman merupakan algoritma yang digunakan untuk mengkompresi suatu file. Teknik algoritma Huffman menggunakan kode yang lebih kecil untuk karakter yang sering digunakan dan kode yang lebih panjang untuk karakter yang tidak begitu sering digunakan. ${ }^{[3]}$

Kode dari Huffman tidak unik, melainkan bergantung pada aturan (rule) ascending/descending order yang digunakan di dalam algoritmanya dan cara memilih probabilitas terendah saat membangun diagram pohon Huffman (Huffman tree). Aturan-aturan tersebut bersifat opsional, tetapi harus konsisten diterapkan. Panjang rata-rata dari codeword selalu sama untuk tree yang berbeda. ${ }^{[3]}$

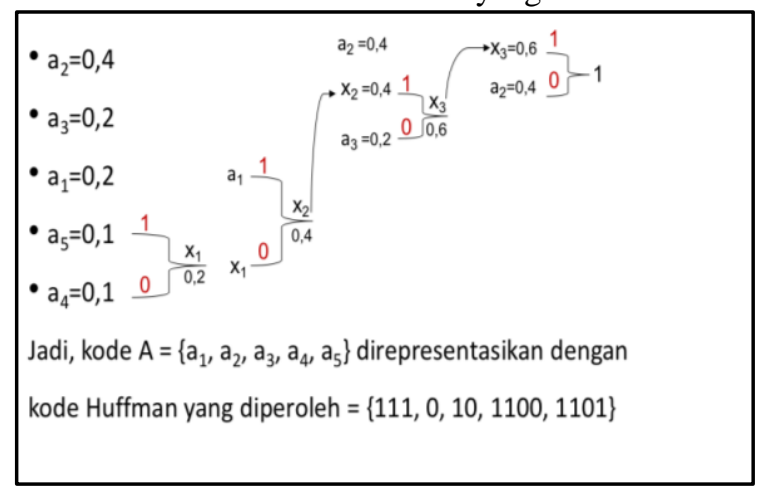

Gambar 2. Contoh pengkodean Huffman

D. Invers 2D-DCT (IDCT2)

Proses decoding adalah dengan Inverse Discrete Cosine Transform 2 Dimensi (IDCT 2 D). Adapun persamaan IDCT-2D adalah sebagai berikut ini :

$$
\begin{aligned}
& f(\mathrm{x}, \mathrm{y}) \\
& =\left(\frac{2}{\sqrt{\mathrm{MN}}}\right) \sum_{\mathrm{u}=0}^{\mathrm{N}-1} \sum_{v=0}^{M-1} \propto(u) . \\
& \propto(v) C(u, v) \cos \left(\frac{\pi(2 x+1) u}{2 \mathrm{~N}}\right) \cos \left(\frac{\pi(2 x+1) v}{2 \mathrm{M}}\right) \\
& \text { dengan nilai } x=0,1,2, \ldots, \mathrm{N}-1 \text { dan nilai } y= \\
& 0,1,2, \ldots \mathrm{M}-1 .
\end{aligned}
$$

\section{METODOLOGI PENELITIAN}

Data yang digunakan adalah data digital citra medis hasil rongent pada penyakit kanker payudara. Berdasarkan studi literatur dan metode yang digunakan, dibuat sebuah perancangan sistem sesuai kondisi keluaran yang diinginkan. Berikut adalah blok diagram rancangan sistem :

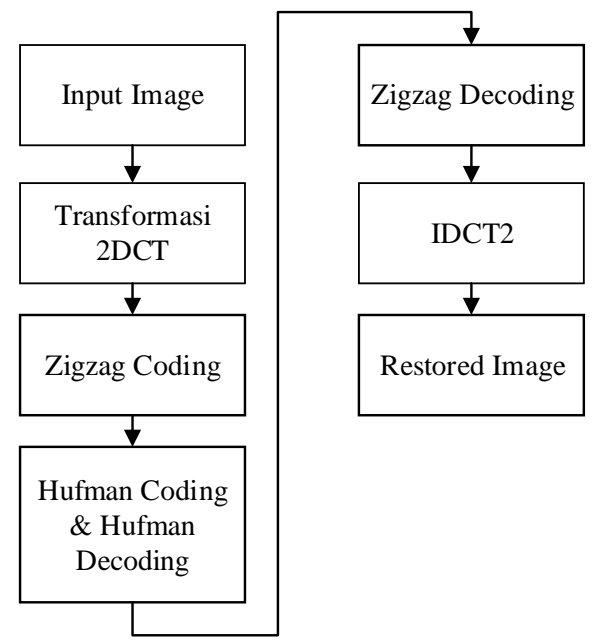

Gambar 3. Diagram Blok Rancangan Sistem Kompresi DCT2

Input citra berupa citra medis digital hasil rontgen penyakit kanker payudara. Citra tersebut diubah ke grayscale. Grayscaling didapatkan dengan menjumlahkan tiga komponen warna red, green dan blue dengan persentase yang berbeda. Berikut ini adalah persamaan grayscale yang digunakan pada penelitian ini.

(6)

$\operatorname{gray}=0,299 * R+0,587 * G+0,114 * B$

Komponen $\mathrm{G}$ (Green) memiliki persentase yang lebih besar dari 2 komponen warna lainnya $\mathrm{R}$ (Red) dan B (Blue) karena citra hasil rontgen lebih dominan komponen warna hijau sehingga warna ini penting untuk ditonjolkan.

\section{A. Transformasi 2D-DCT}

Proses encoding dimulai dengan menginputkan citra grayscale hasil rontgen kanker payudara dan mengubah ukuran citra menjadi 256 × 256 . Setelah itu, citra akan dibagi menjadi $32 \times 32$ blok berukuran $8 \times 8$ piksel setiap blok nya. Setiap blok berukuran $8 \times 8$ akan diproses dengan kuantisasi DCT.

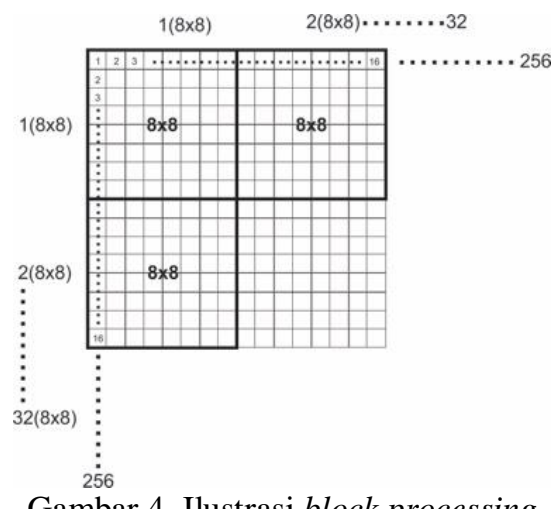

Gambar 4. Ilustrasi block processing 




Gambar 5. Basis fungsi 2D-DCT

Citra yang telah dikuantisasi dengan 2D-DCT terkonsentrasi pada bagian kanan atas piksel citra. Piksel yang berada di posisi semakin ke bagian kiri bawah, nilainya akan cenderung mendekati nol. Pada nilai hasil kuantisasi setiap blok 8x8 dilakukan zigzag coding dengan cara seperti yang telah dijelaskan pada landasan teori. Zigzag coding dilakukan untuk mengubah data piksel menjadi data linier. sebagai masukkan dari Huffman coding.

\section{B. Huffman Coding dan Decoding}

Pada proses huffman coding, setiap data linier yang masuk akan dihitung nilai probabilitas/nilai frekuensi kemunculan nya. Jadi setiap data akan memiliki dua nilai yaitu nilai keabuan dan frekuensi kemunculan. Dari keseluruhan data akan dicari dua buah nilai dengan frekuensi kemunculan terkecil dan dua nilai tersebut akan dijumlahkan nilai frekuensi kemunculannya dan kemudian disimpan nilai frekuensi kemunculan tersebut. Hal tersebut akan dilakukan terus menerus sampai jumlah frekuensi kemunculan sama dengan satu dan semua data linier telah dijumlahkan. Setelah itu data tersebut akan diurutkan berdasarkan probabilitas/nilai frekuensi kemunculannya secara ascending dan akan dimasukan kode ke dalam kode tersebut berdasarkan probabilitasnya, nilai dengan probabilitas tinggi akan mendapatkan kode dengan nilai bit bit lebih kecil. Selanjutnya seluruh data yang dihasilkan akan disimpan dalam file yg diberi nama "dict.mat". Data "dict.mat" tersebut adalah kamus Huffman yang akan digunakan untuk mengkodekan data linear sebagai data hasil pengkodean. Kamus Huffman ini juga yang nanti nya akan digunakan untuk mengembalikan data linear yang telah dikodekan menjadi data aslinya. Berikut ini adalah flowchart yang digunakan untuk membuat kamus Huffman:



Gambar 6. Flowchart Huffman Dictionary

\begin{tabular}{|ll|}
\hline 0 & 0 \\
1 & {$[1,1,0]$} \\
68 & $1 \times 13$ double \\
158 & $1 \times 14$ double \\
207 & $1 \times 14$ double \\
183 & $1 \times 14$ double \\
128 & $1 \times 14$ double \\
58 & $1 \times 13$ double \\
9 & {$[1,0,0,1,1,1,0,1,0]$} \\
\hline
\end{tabular}

Gambar 7. Contoh data dalam dict.mat

Setelah dibuat kamus Huffman, data linier akan dikodekan dengan menggunakan kamus Huffman tersebut. Mula-mula aplikasi akan membaca kamus Huffman dan data linier yang menjadi data masukkan pembuatan kamus Huffman. Selanjutnya akan dilihat nilai pertama pada data linier dengan nilai dalam kamus. Jika nilainya tidak sama, maka akan dilihat nilai selanjutnya pada kamus sampai ditemukan nilai yang sama. Setelah nilainya sama, akan disimpan kode dalam kamus Huffman berdasarkan nilai yang sama tersebut ke dalam file yang diberi nama "compfile.mat". Proses ini dilakukan sampai semua data pada data linier telah habis. Setelah prosess ini selesai, akan disimpan data hasil kompresi yaitu "dcit.mat" dam "compfile.mat". 


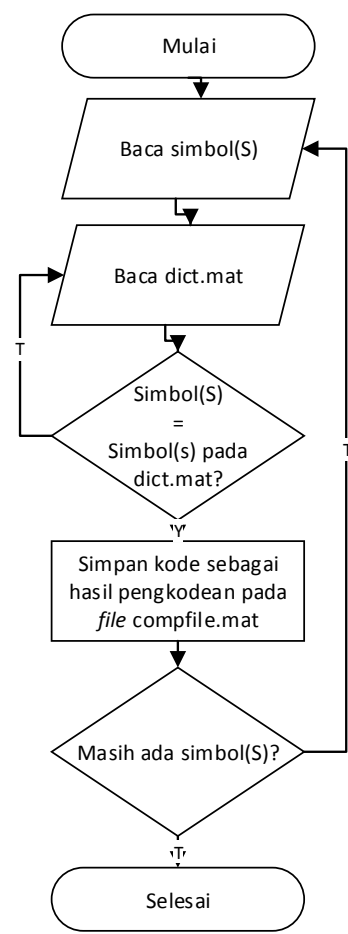

Gambar 8. Flowchart Huffman Encoding

Proses encoding mendapatkan citra hasil kompresi. Untuk mendapatkan citra asli kembali, citra terkompresi harus melalui proses decoding yang merupakan kebalikan dari proses encoding. Awal proses decoding adalah zigzag decoding, setelah zigzag decoding dilakukan proses hufman decoding dan proses yang terakhir adalah proses inverse DCT2 (IDCT2). Citra Asli akan didapatkan kembali setelah semua proses tersebut dilakukan.

Hasil kompresi huffman coding akan disimpan berupa data terkompresi beserta kode huffmannya. Proses decoding dari huffman adalah dengan menggunakan kode huffman yaitu dengan mengambil data dari file terkompresi, kemudian data tersebut dikembalikan lagi ke bentuk aslinya berdasarkan kamus huffman yang telah dibuat. File terkompresi akan kembail menjadi data aslinya.

Proses huffman decoding dimulai dengan membaca file kamus Huffman yang terdapat di "dict.mat" dan file hasil pengkodean yang terdapat di "compfile.mat". Seleteh itu akan dibaca satu kode dari "compfile.mat" lalu akan dicocokan kode tersebut ke dalam kamus Huffman. Jika tidak ada, maka akan ditambahkan satu kode lagi dari "compfile.mat" sehingga kode yang dicocokkan dalam kamus Huffman menjadi dua kode. Setelah kode dalam kamus Huffman ditemukan, akan diambil nilai simbol dalam kamus tersebut dan akan disimpan dalam data. Proses tersebut dilakukan sampai seluruh kode dalam "compfile.mat" telah dibaca dan seluruh data akan disimpan sebagai data linear.

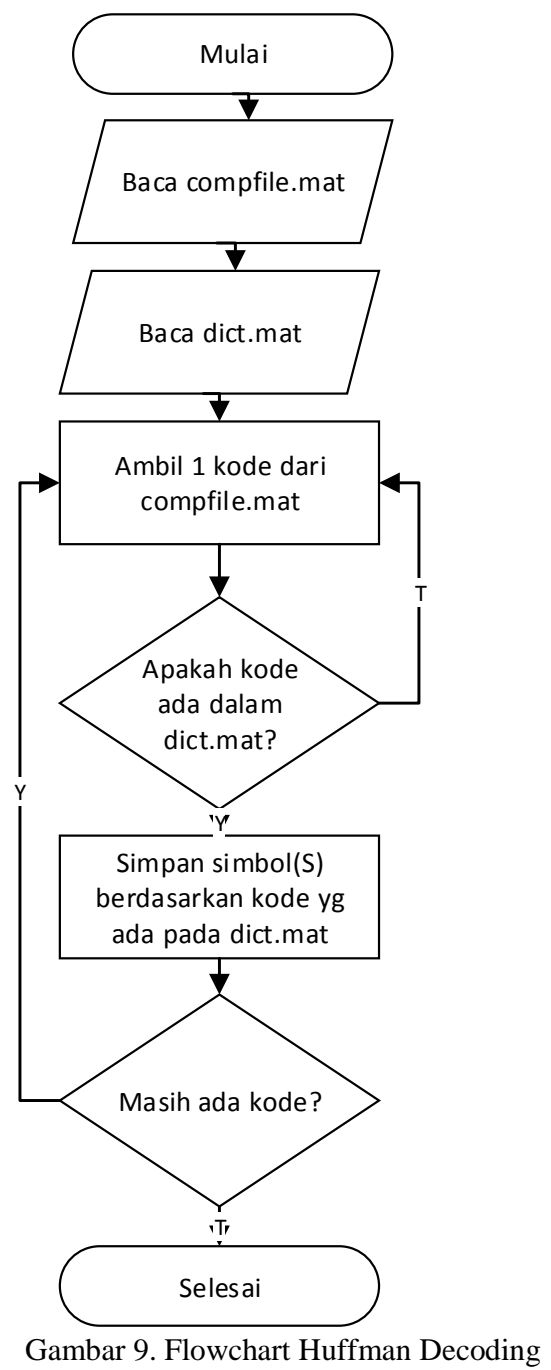

\section{Skenario Pengujian}

Terdapat 24 gambar asli citra medis digital kanker payudara. Pengujian sistem dilakukan sebanyak 4 kali pengujian dengan pengujian alfa sebanyak 3 kali dan pengujian beta sebanyak 1 kali. Pengujian alfa adalah pengujian yang dilakukan dari sisi peneliti. Pengujian alfa yang pertama adalah dengan parameter penggantian nilai pada blok 8x8 dengan nilai nol, pengujian ini akan dijelaskan lebih detail pada bagian selanjutnya. Pengujian alfa ke-dua adalah dengan parameter metode non-hybrid dengan metode hybrid. Pengujian alfa yang ke-tiga yaitu dengan parameter ukuran blok yang digunakan untuk pemrosesan blok kuantisasi. Pada pengujian ini akan dilakukan kompresi dengan blok kuantisasi DCT 8x8, 16x16 dan 32x32.

Pengujian beta adalah pengujian yang dilakukan dengan bantuan ahli medis di bidang radiologi. Pengujian ini dilakukan dengan cara memberikan angket dan memperlihatkan citra asli dan citra kompresi digital.

Pada penelitian ini, untuk menganalisis hasil dari pengujian sistem digunakan Peak Signal to Noise Ratio (PSNR) dan Compression Ratio (CR). Peak Signal to Noise Ratio (PSNR) adalah nilai dalam decibel untuk mengetahui perbandingan citra asli/uji dan citra yang telah dikompresi. PSNR didefinisikan dalam persamaan sebagai berikut ${ }^{[11]}$ : 
$P S N R=20 \log \frac{b}{r m s}$

dengan :

$\mathrm{b}=$ nilai maksimum dari piksel

$\mathrm{rms}=$ root mean square .

Compression Ratio (CR) adalah perbandingan antara citra asli (sebelum kompresi) dengan citra setelah kompresi. Dengan nilai compression ratio dalam persen( $\%$ ) adalah satu dibagi citra asli (sebelum kompresi) dibagi dengan citra setelah kompresi dan hasilnya dikalikan seratus. Dalam persamaan matemetika dapat dituliskan sebagai berikut:

$C R($ dalam persen $)=1 \div\left(\frac{\text { citra sebelum kompres } i}{\text { citra setelah } \text { kompresi }}\right) \times 100$

\section{HASIL DAN PEMBAHASAN}

Berikut adalah gambar citra medis digital. Gambar 9 merupakan gambar asli sebelum dilakukan kompresi. Gambar 10 merupakan gambar setelah dilakukan kompresi 2D-DCT. Gambar 11 merupakan gambar hasil kompresi 2DDCT dengan blok kuantisasi 8x8.

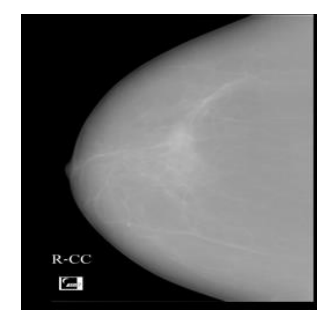

Gambar 10. Citra medis digital kanker payudara

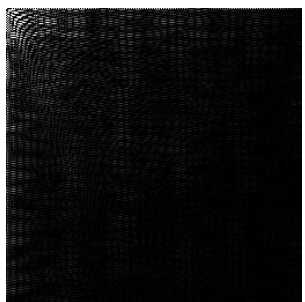

Gambar 11. Hasil 2D-DCT gambar 9

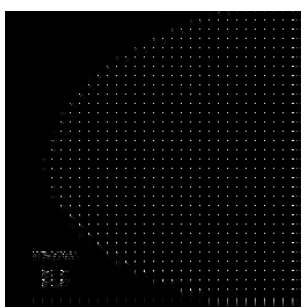

Gambar 12. Hasil 2D-DCT gambar 9 dengan blok 8x8

Citra yang telah dikompres dengan 2D-DCT terkonsentrasi pada bagian kanan atas piksel citra. Piksel yang berada di posisi semakin ke bagian kiri bawah, nilainya akan cenderung mendekati nol.

\section{A. PENGUJIAN ALFA 1}

Pengujian alfa dilakukan dengan menambahkan ketebalan nilai nol "0" pada block processing 2D-DCT. Nilai nol ditambahkan secara bertahap dari mulai 1 sampai 8. Berikut adalah ilustrasinya :

$\begin{array}{llll}7 & 8 & 4 & 6 \\ 8 & 8 & 8 & 7 \\ 2 & 2 & 7 & 6 \\ 8 & 8 & 8 & 4 \\ 6 & 8 & 6 & 6 \\ 1 & 4 & 1 & 2 \\ 3 & 7 & 7 & 6 \\ 5 & 2 & 8 & 1\end{array}$

(a)

$\begin{array}{llll}7 & 8 & 4 & 6 \\ 8 & 8 & 8 & 7 \\ 2 & 2 & 7 & 6 \\ 8 & 8 & 8 & 4 \\ 6 & 8 & 6 & 6 \\ 1 & 4 & 1 & 2 \\ 3 & 7 & 7 & 6 \\ 5 & 2 & 8 & 1\end{array}$

(b)

$\begin{array}{llll}7 & 8 & 4 & 6 \\ 8 & 8 & 8 & 7 \\ 2 & 2 & 7 & 6 \\ 8 & 8 & 8 & 4 \\ 6 & 8 & 6 & 6 \\ 1 & 4 & 1 & 2 \\ 3 & 7 & 7 & 0 \\ 5 & 2 & 0 & 0\end{array}$

(c)

Gambar 12. Matrik blok processing

Matrik (a) adalah contoh blok processing tanpa penambahan nilai nol, matrik (b) adalah matrik dengan penambahan nol dengan ketebalan 4 dan matrik (c) adalah matrik dengan penambahan nol dengan ketebalan 6 .

Tabel 1. Hasil pengujian Alfa 1

\begin{tabular}{|l|l|r|}
\hline (d) & CR & \multicolumn{1}{l|}{ PSNR } \\
\hline $\mathbf{d}=\mathbf{0}$ & 2.909628 & 40.29386 \\
\hline $\mathbf{d = 1}$ & 3.007416 & 32.50489 \\
\hline $\mathbf{d = 2}$ & 3.250988 & 29.29245 \\
\hline $\mathbf{d = 3}$ & 3.604189 & 26.9395 \\
\hline $\mathbf{d}=\mathbf{4}$ & 4.223958 & 25.23385 \\
\hline
\end{tabular}




\begin{tabular}{|r|r|r|}
\hline$d=5$ & 5.285388 & 23.14745 \\
\hline$d=6$ & 7.152907 & 21.22495 \\
\hline$d=7$ & 14.2167 & 18.1483 \\
\hline
\end{tabular}

$\mathrm{d} \quad$ = banyaknya kedalaman nilai nol

$\mathrm{CR}=$ compression ratio

PSNR = peak signal to noise ratio

Berdasarkan hasil pengujian alfa 1 , diperoleh data seperti terlihat pada tabel 1. Dari data tersebut dapat diketahui bahwa semakin banyak kedalaman nilai nol yang ditambahkan, maka semakin besar pula nilai dari compression ratio $(\mathrm{CR})$ namun nilai dari peak signal noise ratio (PSNR) semakin menurun. Nilai CR terbesar dimiliki oleh pengujian dengan kedalaman nilai nol terbanyak $(\mathrm{d}=7)$ yaitu 14. 2167 atau data terkompresi menjadi $7.033 \%$ dari data aslinya sedangkan nilai CR terkecil dimiliki oleh pengujian tanpa kedalaman nilai nol $(\mathrm{d}=0)$ yaitu 2.909628 atau data terkompresi menjadi $34.36 \%$ dari data aslinya. Nilai PSNR terbesar dimiliki oleh pengujian tanpa kedalaman nilai nol $(\mathrm{d}=0)$ dengan nilai $40.29386 \mathrm{~dB}$ sedangkan nilai PSNR terkecil dimiliki oleh pengujian dengan kedalaman nilai nol terbanyak $(\mathrm{d}=7)$ yaitu 18.1483 $\mathrm{dB}$.

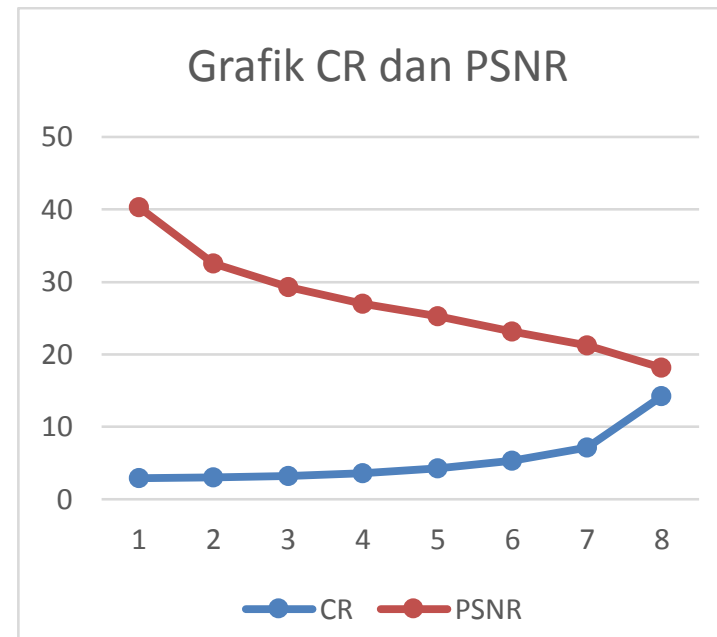

Gambar 13. Grafik Compression Ratio dan PSNR Pengujian Alfa 1

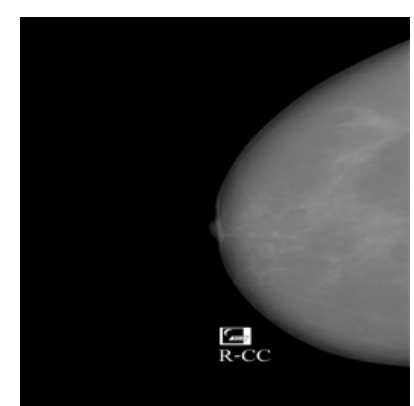

Gambar 14. Gambar asli objek 1

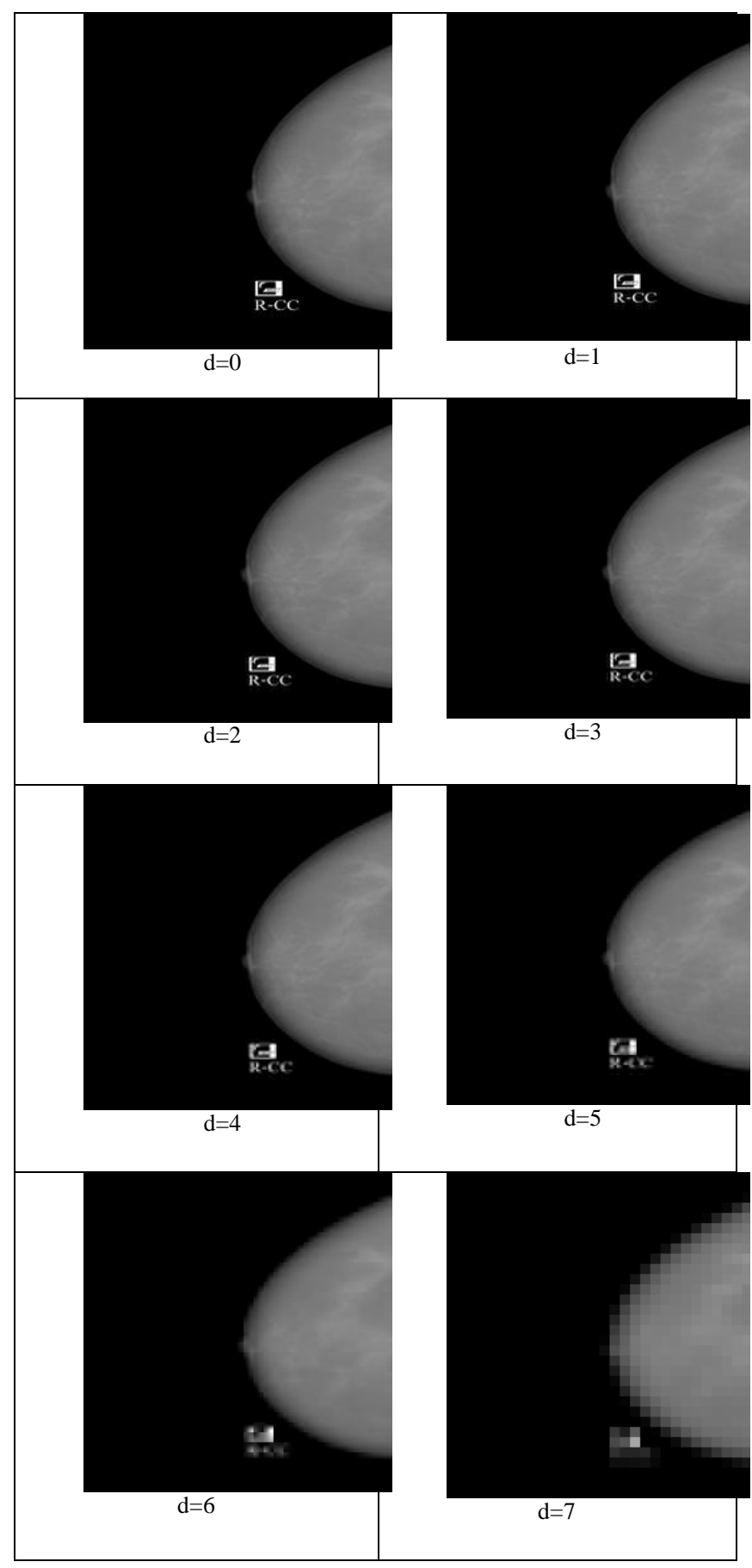

Gambar 15. Hasil kompresi objek 1 dengan kedalaman nilai nol (d) yang berbeda-beda.

Semakin dalam nilai nol pada proses tranformasi/kuantisasi 2D-DCT maka akan semakin besar nilai kompresi data citra medis digital, namun juga akan semakin banyak informasi penting yang hilang pada citra medis digital. Berdasarkan pengujian alfa 1 ini, kompresi terbaik dengan menggunakan nilai $\mathrm{d}=0$, dengan kompresi rasio sebesar 2,9.

\section{B. PENGUJIAN ALFA 2}

Pengujian alfa 2 dilakukan dengan membandingkan metode hybrid dengan metode non-hybrid, yaitu masingmasing metode DCT-2D dan Huffman. Pengujian ini 
bertujuan untuk mengamati pengaruh sistem hybrid dalam kompresi citra medis digital. Pada pengujian ini dapat terlihat bahwa sistem hybrid dapat meningkatkan performasi dari compression ratio (citra hasil kompresi) dari 48,4799\% menjadi 34,368 \% dengan nilai PSNR yang relatif baik.

Tabel 2. Tabel Pengujian Alfa 2

\begin{tabular}{|c|c|r|c|}
\hline Metode & CR & CR $(\%)$ & $\begin{array}{c}\text { PSN } \\
\text { R }\end{array}$ \\
\hline Hybrid & $\begin{array}{c}2.90962 \\
8\end{array}$ & 34.368 & 40.29 \\
\hline $\begin{array}{c}\text { Huffma } \\
\text { n }\end{array}$ & $\begin{array}{r}2.06284 \\
9\end{array}$ & $\begin{array}{r}48.476 \\
6\end{array}$ & inf \\
\hline DCT & 0 & 0 & inf \\
\hline
\end{tabular}

\section{Perbandingan Sistem \\ Hybrid dan non Hybrid}

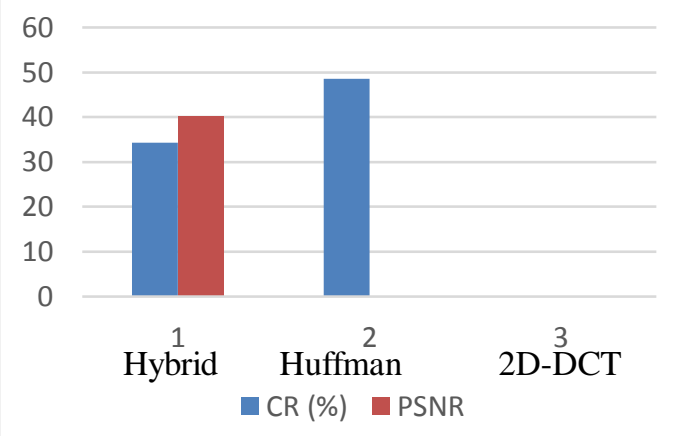

Gambar 16. Grafik Pengujian Alfa 2

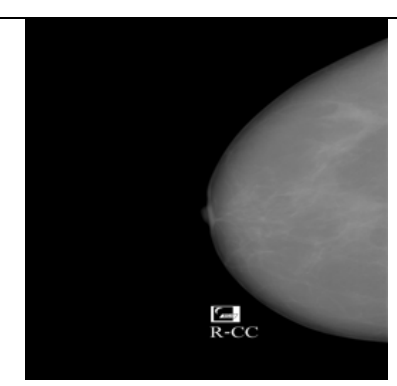

Gambar asli

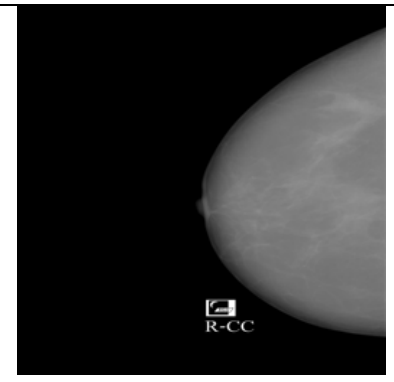

Kompresi Huffman

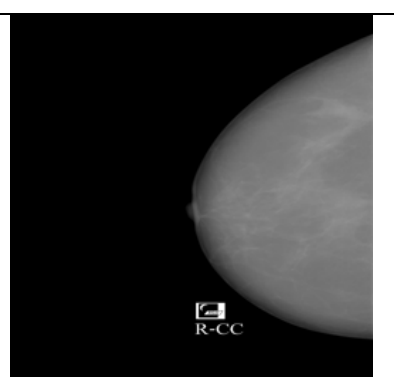

Kompresi 2D-DCT

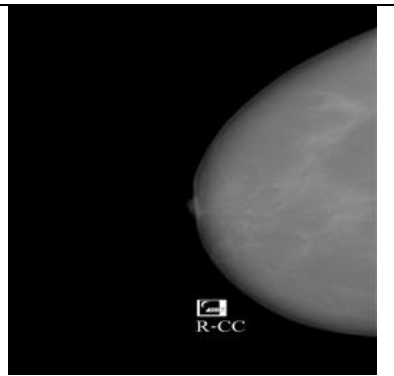

Kompresi Hybrid (2D-

DCT dan Huffman)
Gambar 17. Hasil kompresi objek 1 dengan $\mathrm{d}=0$ dan metode yang berbeda
Berdasarkan pengujian nilai kedalaman d, didapatkan nilai kompresi terbaik menggunakan $\mathrm{d}=0$ maka pada pengujian alfa 2 digunakan $\mathrm{d}=0$ dengan metode non-hybrid dan hybrid. Didapatkan hasil terbaik menggunakan kombinasi 2 metode 2D-DCT dan Huffman.

\section{PENGUJIAN ALFA 3}

Dalam pengujian ini, kompresi dilakukan dengan 3 ukuran blok yang berbeda untuk pemrosesan blok pada kuantisasi DCT. Ukuran blok yang digunakan adakan ukuran $8 \times 8$ blok, $16 \times 16$ blok dan 32x32 blok.

Tabel 3. Hasil Pengujian Alfa 3

\begin{tabular}{|c|c|c|c|}
\hline $\begin{array}{c}\text { Ukuran } \\
\text { Blok }\end{array}$ & CR & $\begin{array}{c}\text { CR } \\
(\%)\end{array}$ & $\begin{array}{c}\text { PSNR(d } \\
\text { B) }\end{array}$ \\
\hline $8 \times 8$ & $\begin{array}{c}2.90962 \\
8\end{array}$ & 34.36 & $\begin{array}{c}62.5242 \\
4\end{array}$ \\
\hline $16 \times 16$ & $\begin{array}{c}2.91549 \\
4\end{array}$ & 34.29 & $\begin{array}{c}62.4095 \\
8\end{array}$ \\
\hline $32 \times 32$ & $\begin{array}{c}2.70951 \\
3\end{array}$ & $\begin{array}{l}36.90 \\
7\end{array}$ & $\begin{array}{c}62.1250 \\
3\end{array}$ \\
\hline
\end{tabular}

Pada pengujian alfa 3 terlihat adanya peningkatan compression ratio $(C R)$ namun nilai PSNR cenderung tidak berubah. Artinya, ukuran blok pada kuantisasi DCT-2D tidak memberikan pengaruh yang signifikan pada kompresi citra medis digital.

\section{Grafik Pengujian Alfa 3}

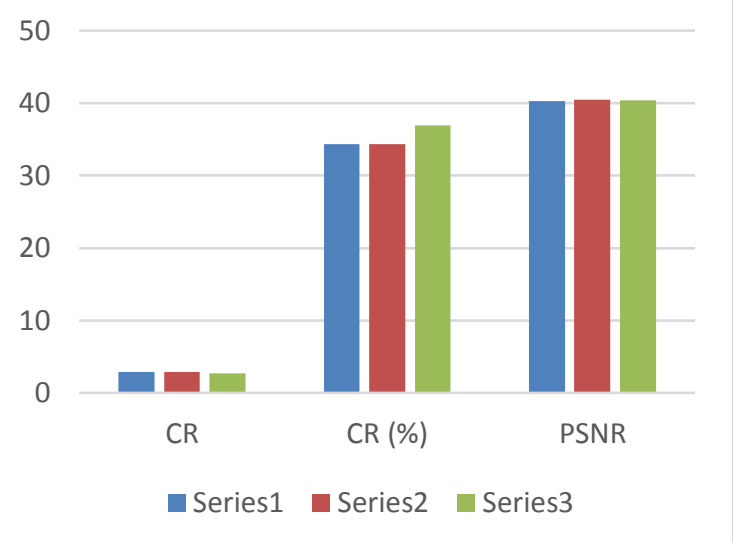

Gambar 18. Grafik Pengujian Alfa 3

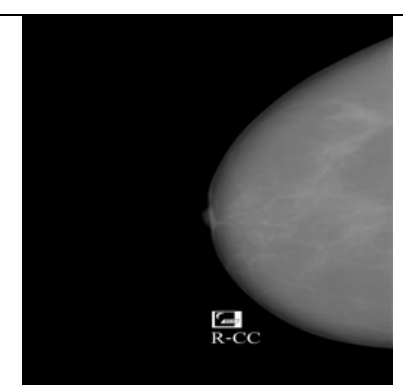

Gambar asli

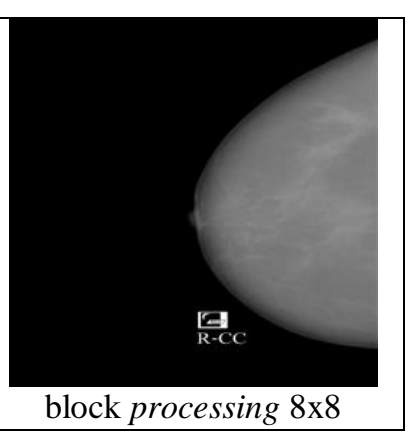



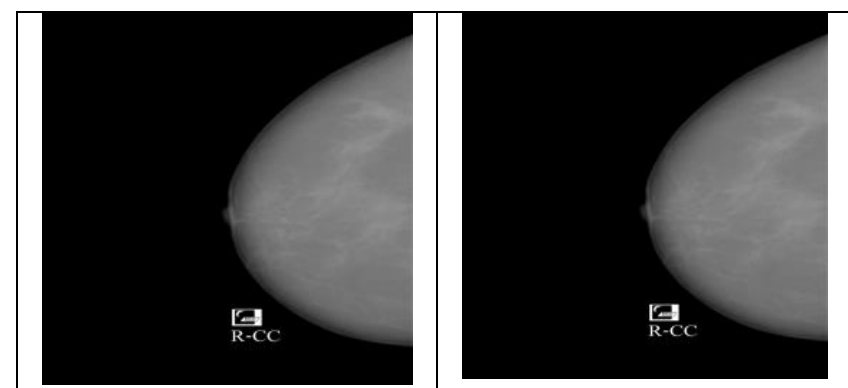

block processing $16 \times 16$

block processing $32 \times 32$

Gambar 19. Hasil kompresi hybrid dengan block processing yang berbeda

Berdasarkan hasil pengujian alfa 3, diketahui bahwa ukuran block processing tidak memberikan pengaruh hasil kompresi yang signifikan pada citra medis digital yang diujikan. Block processing 8x8 lebih baik dari block 16x16 dan 32x32. Hanya saja, perbedaannya sangat tipis. Semakin kecil ukuran block processing yang digunakan maka akan semakin banyak juga proses komputasinya sehingga waktu komputasinya juga relatif lebih lama untuk input data citra digital yang sama.

\section{PENGUJIAN BETA}

Dalam pengujian beta, digunakan angket untuk mengetahui kualitas gambar dalam pandangan ahli medis dalam hal ini ahli radiologi. Pengujian ini dilakukan oleh dr. Pandu,Sp.Rad yang bekerja di RS Al - Islam Bandung. Angket tersebut diujikan untuk citra pengujian alfa 1. Angket yang diberikan adalah sebagai berikut :

Tabel 4. Daftar kualifikasi pengujian beta

\begin{tabular}{|c|c|}
\hline No & Daftar Pertanyaan \\
\hline 1 & $\begin{array}{c}\text { Kejelasan gambar hasil kompresi } \\
\text { dari segi bentuknya }\end{array}$ \\
\hline 2 & $\begin{array}{l}\text { Kejelasan gambar hasil kompresi } \\
\text { dari segi teksturnya }\end{array}$ \\
\hline 3 & $\begin{array}{c}\text { Keakuratan tanda-tanda penyakit } \\
\text { kanker payudara melalui gambar } \\
\text { hasil kompresi }\end{array}$ \\
\hline 4 & $\begin{array}{l}\text { Hasil kompresi dapat digunakan } \\
\text { untuk diagnosis penyakit sesuai } \\
\text { dengan data asli (non kompresi) }\end{array}$ \\
\hline
\end{tabular}

Pada pengujian beta diperoleh hasil sebagai berikut:

Tabel 4. Tabel hasil pengujian beta

\begin{tabular}{|r|r|r|r|r|}
\hline & $\begin{array}{c}\text { Pert } \\
\text { a-nyaan } \\
1\end{array}$ & $\begin{array}{r}\text { Pert } \\
\text { a-nyaan } \\
2\end{array}$ & $\begin{array}{r}\text { Pert } \\
\text { a-nyaan } \\
3\end{array}$ & $\begin{array}{r}\text { Pert } \\
\text { a-nyaan } \\
4\end{array}$ \\
\hline \multicolumn{5}{|c|}{ Responden A } \\
\hline $\mathrm{li}$ & 3 & 3 & 3 & 3 \\
\hline $\mathrm{d}=$ & 3 & 3 & 3 & 3 \\
\hline
\end{tabular}

\begin{tabular}{|c|c|c|c|c|}
\hline $1^{d=}$ & 3 & 3 & 3 & 3 \\
\hline $2^{d=}$ & 3 & 3 & 3 & 3 \\
\hline $3^{d=}$ & 3 & 3 & 3 & 3 \\
\hline $4^{d=}$ & 3 & 3 & 3 & 1 \\
\hline $5^{d=}$ & 3 & 3 & 3 & 1 \\
\hline $6^{d=}$ & 3 & 3 & 1 & 1 \\
\hline $7^{d=}$ & 3 & 3 & 1 & 1 \\
\hline \multicolumn{5}{|c|}{ Responden B } \\
\hline $\mathrm{li}^{\text {As }}$ & 4 & 3 & 3 & 2 \\
\hline $0^{d=}$ & 4 & 4 & 3 & 2 \\
\hline $1^{d=}$ & 4 & 4 & 2 & 2 \\
\hline $2^{d=}$ & 4 & 3 & 2 & 2 \\
\hline $3^{d=}$ & 4 & 3 & 2 & 2 \\
\hline $4^{d=}$ & 4 & 3 & 2 & 2 \\
\hline $5^{d=}$ & 4 & 1 & 1 & 1 \\
\hline $6^{d=}$ & 2 & 1 & 1 & 1 \\
\hline $7^{d=}$ & 1 & 1 & 1 & 1 \\
\hline
\end{tabular}

Dari data tersebut dapat diketahui bahwa kedalaman nilai nol masih dapat terlihat baik sampai kedalaman nilai nol $\mathrm{d}=3$, sedangkan untuk kedalaman nilai nol $\mathrm{d}=4$ sampai $\mathrm{d}=7$ data sudah tidak dapat didiagnosis oleh tim medis bagian radiologi.

Berikut sampel uji yang digunakan dalam penelitian ini.

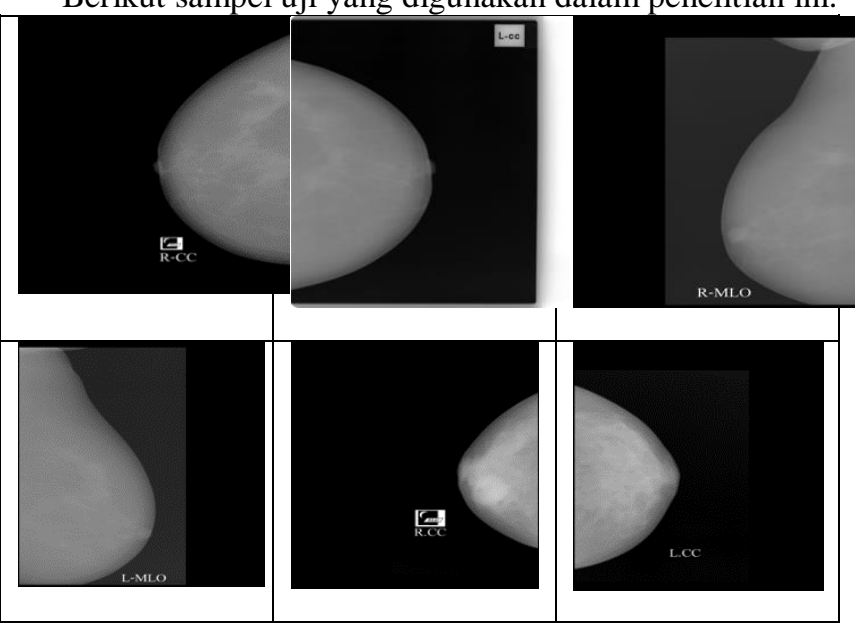




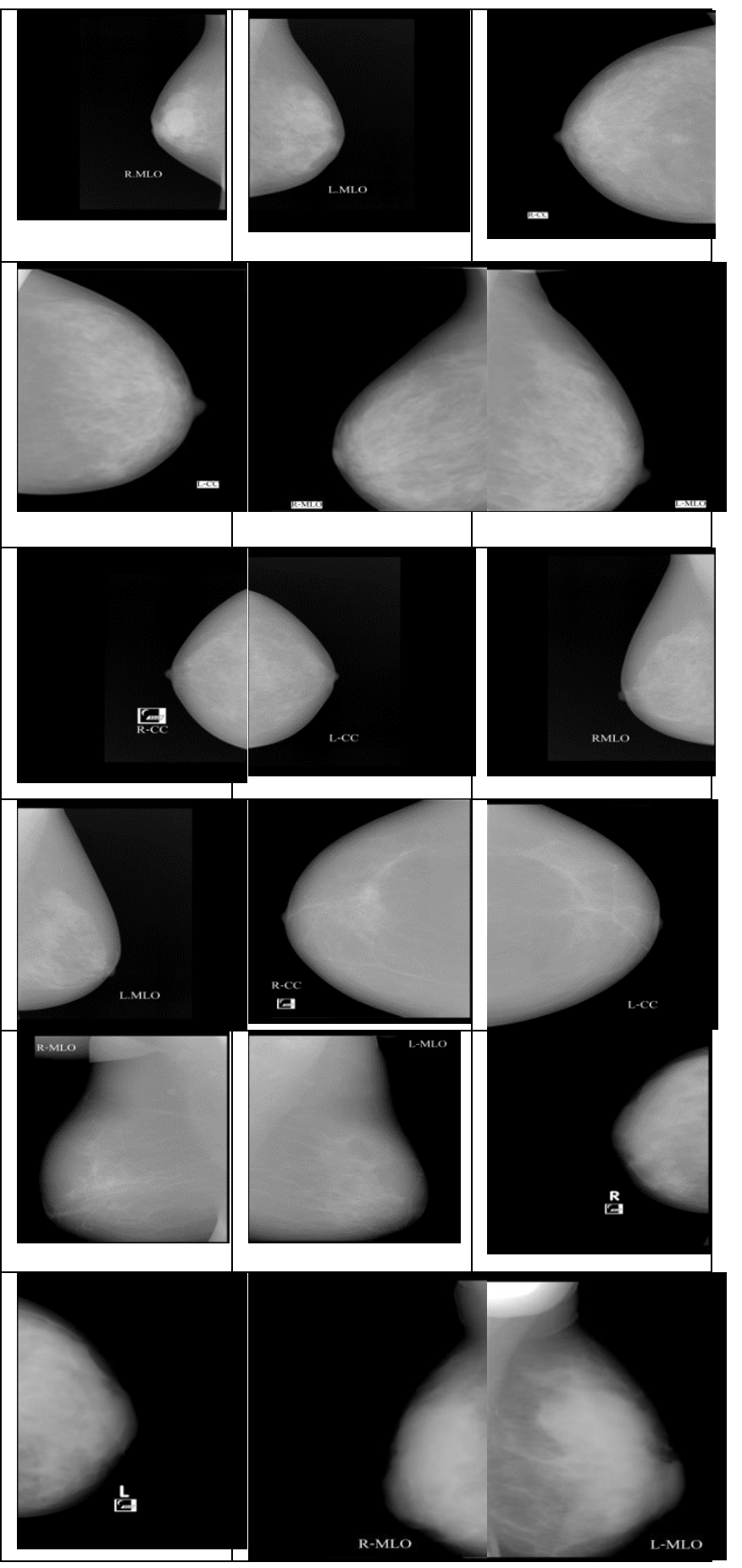

Gambar 20. Sampel uji citra medis digital kanker payudara

\section{KESIMPULAN}

1) Kompresi citra medis hasil rongent untuk data hasil ronget kanker payudara dengan metode hybrid two dimentional discrete cosine transform dan Huffman coding mendapatkan hasil komprsi terbaik yaitu 7.033 $\%$ dengan nilai PSNR $18.143 \mathrm{~dB}$.

2) Nilai PSNR terbaik dari metode hybrid two dimentional discrete cosine transform dan Huffman coding adalah $40.2938 \mathrm{db}$ dengan nilai $\mathrm{CR}=34.36 \%$.
3) Penambahan kedalaman nilai nol (d) dapat meningkatkan compression ratio namun secara bersamaan menurunkan peak signal noise ratio.

4) Metode hybrid two dimentional discrete cosine transform dan Huffman coding meninggkatkan compression ratio metode non hybrid discrete cosine transform dan non hybrid Huffman Coding dari dari $48,4799 \%$ menjadi $34,368 \%$ dengan nilai PSNR yang relatif baik.

5) Kedalaman nilai nol pada proses kuantisasi (d) yang terbaik yang didapat adalah $(\mathrm{d}=0),(\mathrm{d}=1),(\mathrm{d}=2)$ dan $(d=3)$. Sedangkan untuk nilai $(d=4)$ sampai $(d=7)$ citra sudah tidak dapat didiagnosa.

Saran pengembangan sistem ini, dapat diintegrasikan dengan alat rongent yang lazim digunakan pada rumah sakit umum. Selain itu, dapat digunakan metode kompresi lainnya yang lebih baik.

\section{UCAPAN TERIMA KASIH}

Ucapan terima kasih diberikan kepada unit radiologi RS Al-Islam Bandung, khususnya dr. Pandu,Sp.Rad. yang telah memberikan dukungan pada penelitian kompresi citra medis digital pada penyakit kanker payudara.

\section{DAFTAR PUSTAKA}

[1] Amit S.,Prof Pravin S., Kulkarni.2015.Medical Image Compression Using Hybird Technique.International Journal of Scientific Enginering and Aplied Science (IJSEAS).

[2] Arya, Vivek. Medical Image Compression Using Two Dimentional Discrete Cosine Transform. 2015. International Journal of Electrical and Eletronics Research ISSN 2348-6988 Vol. 3, Issue 1, pp: (156164).

[3] Irmalia Suryani. 2011 . Implementasi Metode Huffman Sebagai Teknik Kompresi Citra. Malang.Jurnal Elektro ELTEK Vol. 2, No. 2, Oktober ISSN: 2086-8944 Institut Teknologi Malang.

[4] Kementrian Kesehatan RI. 2015. INFODATIN (Pusat Data dan Informasi Kementrian Kesehatan RI): Stop Kanker. Jakarta: Pusat Data dan Informasi Kemetrian Kesehatan Republik Indonesia.

[5] Madhu Ahuja, Sanjivani Shantaiya. 2015. A Review on Image Compression using DCT and DWT. International Journal for Scientific Research \& Development Vol. 3, Issue 10, 2015.

[6] Moh'd Ali Moustafa Alsayyh, Prof. Dr. Dzulkifli Mohamad, Waheeb abu-ulbaa. 2013. Image Compression Using Discrete Cosine Transform and Discrete Wavelet Transform. International Journal of Innovative Research in Computer and Communication Engineering.

[7] Ramandeep Kaur Grewal. Navneet Randhawa. 2012. Image Compression Using Discrete Cosine Transform \& Discrete Wavelet Transform . International Journal of Computing \& Business Research.

[8] Andika Satyapratama, Widjianto, Mahmud Yunus. 2016. Analisis Perbandingan Algoritma Lzw dan 
Huffman Pada Kompresi File Gambar BMP dan PNG. Jurnal Teknologi Informasi.

[9] Raras Krasmala, Arif Budimansyah Purba, U. Tresna Lenggana. 2017. Kompresi Citra Dengan Menggabungkan Metode Discrete Cosine Transform (DCT) dan Algoritma Huffman. JOIN.

[10] Sarvarinder S., Er Sarabjit Singh. 2015.Medical Image Compression Using Discrete Cosine Transform. International Journal of Science Reaserch Enginering and Technology (IJSRET).

[11] Yusra A. Y. Al-Najjar, Dr. Der Chen Soong.2012. Comparison of Image Quality Assessment:PSNR, HVS, SSIM, UIQI.International Journal of Scientific \& Engineering Research, Vol 3,Issue 8. 